\title{
Nutrition Practices in the Belgian Fruit Industry
}

Tom Deckers and Hilde Schoofs

AdDITIONAL INDEX WORDS. soil application, foliar nutrition

Summary. Nutrition is an important orchard management factor. In integrated fruit production (IFP) there is a tendency to reduce the impact of some elements like nitrogen from soil applications and to replace them by leaf applications. For some elements like magnesium or manganese a leaf application can be a very efficient way to prevent deficiency symptoms on the leaves; for other elements these effects can not be proved sufficiently. In this paper we discuss some standard nutritional practices of Belgian fruit growing; for some of them there is sufficient scientific support for others there is not. A general overview is given in which the different foliar applications are positioned in function of the phenological evolution of fruit trees.

$\mathrm{N}$ utrition requirements in Belgian orchards are based on a combination of regular analysis of the soil every 3 to 4 years, combined with regular leaf analysis every year. As a result of ecological concerns in Europe there is a growing tendency to apply elements like $\mathrm{N}, \mathrm{P}, \mathrm{K}$, and $\mathrm{Mg}$ within the herbicide strips under fruit trees and to reduce in this way the total amount applied per hectare. For other elements like $\mathrm{Ca}$ a broadcast application over the total orchard area is still the standard practice. Other elements like B, Mn, and $\mathrm{Zn}$ can be very efficiently applied to the leaves. Also foliar applications of $\mathrm{Mg}$ can be very efficient.

Foliar nutrition is important in Belgian fruit production systems and is considered as a complement to standard nutrition practices; some growers refuse to use foliar nutrition completely while others are convinced that foliar nutrition is essential for nutrition management in a modern orchard. There are many questions around fruit tree nutrition that are not sufficiently understood and which need further research. In this paper we summarize some of our experience in nutrition of apple (Malus $\times$ domestica) and pear (Pyrus communis) made during a period of 20 years of activity in the Pomology Department at the Royal Research Station of Gorsem, Belgium. 


\section{Soil analysis}

Nutrition requirements in Belgium are based on annual leaf analysis and soil analysis every 3 or 4 years. Soil analysis gives information about the soil $\mathrm{pH}$ and organic matter content which are both very important factors for orchard nutrition. In addition soil analysis gives information about soil texture and the amount of available nutrients. However, nutrient uptake by fruit trees is not only dependent on soil content but also by antagonisms with other nutrients. Soils with a high $\mathrm{K}$ content are likely to have problems of $\mathrm{Mg}$ deficiency and this deficiency will appear earlier in light-textured soils. Information on the homogeneity of the soil profile in an orchard is also of interest and is available on maps indicating the soil suitability for specific crops.

\section{Leaf analysis}

Samples for standard leaf analysis are taken during summer on the middle leaves of 1-year-old shoots. But from practical point of view it is also interesting to have an earlier sample just after flowering. However, it has not been determined which leaves should be chosen; is it necessary to take the small cluster leaves around the flower buds, or can other leaves be taken around the spurs of the 2-year-old wood or on the bourse shoots? There is a need for good reference values for different types of leaves collected in the beginning of the season. With good reference values for early samples, it may be possible to correct deficiencies quickly for some important nutrients such as $\mathrm{N}, \mathrm{Mn}$, or $\mathrm{Mg}$. A comparison of the nutritional status among years is also an important advantage of the yearly leaf analysis. This allows an evaluation of the effects of nutrient applications, pruning, weed control and other management techniques. It is also possible to compare the nutritional status of vigorous trees and normal growing trees, with the aim of explaining differences in growth patterns.

\section{Standard leaf nutrient application schedule}

A standard leaf nutrient application schedule starts in the beginning of the season with a $\mathrm{Cu}$ treatment in the silver tip stage as the first fungicide treatment. Before bloom in the pink bud stage a $\mathrm{Mg}$ treatment is often combined with a B treatment with the aim to increase the leaf quality around the flower clusters. During the same period leaf urea applications are applied. In the bloom period B applications at a reduced dose ( $10 \%$ of the standard dose) are made under poor pollination conditions. The standard $\mathrm{B}$ application is made as $313 \mathrm{~g}(0.69$ lb) of B applied as Solubor DF (BASF Aktiengesellschaft, Limburgerhof, Germany).

In the postfloral period, three treatments of magnesium sulphate $\left(\mathrm{MgSO}_{4}\right)$ and $\mathrm{B}$ are alternated with three treatments of $\mathrm{Mn}$ and $\mathrm{Zn}$. The $\mathrm{Mn}$ and $\mathrm{Zn}$ treatments can be applied as $\mathrm{Mn}-\mathrm{Zn}$ containing fungicides or with special $\mathrm{Mn}$ and $\mathrm{Zn}$ containing leaf nutrition solution. After the June drop fruit fall, summer treatments with $\mathrm{Ca}$ are made on apple under nitrate or chloride form. These treatments are often combined with $\mathrm{Mn}$ applications on bicolored apple cultivars such as 'Jonagold' with the aim of improving the green background color of the fruit. At the end of the season urea leaf applications try to restore the $\mathrm{N}$ reserve level and during leaf fall period, copper treatments synchronize the leaf fall and prevent infections of nectria canker (Nectria galligena).

Nitrogen. Leaf analysis is the standard method to evaluate the $\mathrm{N}$ status of fruit trees and will often identify $\mathrm{N}$ deficiency immediately. The critical level of visual $\mathrm{N}$-deficiency symptoms on the leaves of 'Jonagold' apple trees was $2 \%$ expressed as percentage of the dry weight and the $\mathrm{N}$ level in apple trees should be between $2.2 \%$ and $2.4 \%$.

Nitrogen mineralization ( $\mathrm{N}-\mathrm{min})$ is measured in the soil profile at three levels of depth: from 0 to $30 \mathrm{~cm}$ (11.8 inches), from 30 to $60 \mathrm{~cm}$ (23.6 inches) and from 60 to $90 \mathrm{~cm}$ (35.4 inches) and for each depth the amount of nitrate- $\mathrm{N}\left(\mathrm{NO}_{3}-\mathrm{N}\right)$ and ammonium$\mathrm{N}\left(\mathrm{NH}_{4}-\mathrm{N}\right)$ is determined and expressed in kilograms $\mathrm{NO}_{3}-\mathrm{N}$ and $\mathrm{NH}_{4}{ }_{-}^{-}$ $\mathrm{N}$ and these data give the $\mathrm{N}$-min profile of the orchard at a given moment during season. $\mathrm{N}$-min determination in the soil profile is an increasing practice for orchards in Belgium. N-min profiles in the soil can indicate the risk for $\mathrm{NO}_{3}$ leaching to the groundwater which is becoming an important risk factor in modern horticulture. Under normal fruit growing practices where total $\mathrm{N}$ doses per year are relatively low from 30 to $60 \mathrm{~kg} \cdot \mathrm{ha}^{-1}$ (26.7 to 53.4 $\mathrm{lb} /$ acre) applied on the herbicide strip for 'Jonagold' apple trees and 'Conference' pear trees, it is unlikely that $\mathrm{NO}_{3}$ pollution occurs. However, for very productive apple cultivars like 'Golden Delicious' application rates may reach $100 \mathrm{~kg} \cdot \mathrm{ha}^{-1}(89 \mathrm{lb} /$ acre $)$ of $\mathrm{N}$ each year. Foliar $\mathrm{N}$-application after harvest is a common practice in modern IFP systems. These $\mathrm{N}$ applications of urea are made to increase leaf decomposition and to reduce overwintering inoculum of the scab fungus (Venturia inaequalis) on apple trees and (Venturia pyrina) on pear trees. The amount of urea applied varies between 3 and $20 \mathrm{~kg} \cdot \mathrm{ha}^{-1}$ (2.67 and $17.8 \mathrm{lb} / \mathrm{acre}$ ) of N. In some years with early winter frost in November, there is a risk of insufficient winter hardiness of the flower buds if high doses of urea are applied at the end of the season. This risk is more pronounced with pear than apple trees. Leaf applications of nitrogen can be very useful after serious winter damage to the bark of young trees. Under these circumstances the normal xylem flow is interrupted and urea applications can bridge the gap early in season and allow natural reparation of the vascular system. In many orchards, standard soil applications of $30 \mathrm{~kg}(66 \mathrm{lb})$ of $\mathrm{N}$ early in season some weeks before bloom are complemented with leaf applications of urea during the season. On pear trees, foliar $\mathrm{N}$ applications are made during the last weeks before harvest with the aim of improving the green background color of the fruit.

Phosphorus and potassium NuTRITION. P and $\mathrm{K}$ are both elements that are normally applied to the herbicide strip but they may also be applied as foliar sprays on apple and pear trees. Pear trees have a higher K requirement than apple trees and $\mathrm{K}$ is important for the final fruit quality of the pears at harvest. Therefore regular foliar treatments with $\mathrm{K}$ containing nutrients sprays is a common practice in European pear growing. Foliar K applications are often combined with $\mathrm{P}$ applications in different $\mathrm{P}-\mathrm{K}$ foliar spray formulations. However, foliar applications of $\mathrm{P}$ and $\mathrm{K}$ do not always affect the mineral composition of the fruit or the leaves (Table 1).

In this trial on 'Conference' pear, $\mathrm{P}$ and K-containing spray formulations were applied during season starting the first application after the June 
Table 1. Effect of $P$ and $K$ foliar applications on the mineral composition of 'Conference' pear fruit and leaves in 1997.

\begin{tabular}{|c|c|c|c|c|c|c|}
\hline \multirow[b]{2}{*}{ Treatment } & \multicolumn{2}{|c|}{$\begin{array}{c}\text { Applications } \\
{\left[\text { frequency } \times \text { rate }\left(\mathrm{g} \cdot \mathrm{ha}^{-1}\right)\right]}\end{array}$} & \multicolumn{2}{|c|}{$\begin{array}{c}\text { Fruit } \\
(\% \text { dry wt })\end{array}$} & \multicolumn{2}{|c|}{$\begin{array}{c}\text { Leaves } \\
(\% \text { dry } w t)\end{array}$} \\
\hline & $\mathbf{P}$ & $\mathrm{K}$ & $\mathbf{P}$ & $\mathbf{K}$ & $\mathbf{P}$ & $\mathbf{K}$ \\
\hline Untreated & -- & & 0.086 & 1.11 & 0.148 & 1.56 \\
\hline $00-30-40$ & $5 \times 396$ & $5 \times 996$ & 0.093 & 1.13 & 0.155 & 1.56 \\
\hline Foliphos & $4 \times 893$ & $4 \times 140$ & 0.101 & 1.08 & 0.162 & 1.44 \\
\hline $\mathrm{KH}_{2} \mathrm{PO}_{4}$ & $6 \times 595$ & $6 \times 744$ & 0.108 & 1.15 & 0.167 & 1.47 \\
\hline $\mathrm{KNO}_{3}{ }^{4}$ & $6 \times 573$ & & 0.088 & 1.03 & 0.160 & 1.44 \\
\hline
\end{tabular}

${ }^{\mathrm{y}} 00-30-40=0 \mathrm{~N}-13.2 \mathrm{P}-33.2 \mathrm{~K}=13.2 \% \mathrm{P}$ and $33.2 \% \mathrm{~K}$

${ }^{x}$ Foliphos (Goëmar, Saint Malo, France) $=12.8 \% \mathrm{P}$ and $4.2 \% \mathrm{~K}$.

${ }^{\mathrm{w}} \mathrm{KH}_{2} \mathrm{PO}_{4}$ (potassium dihydrogen orthophosphate) $=22.9 \% \mathrm{P}$ and $28.6 \% \mathrm{~K}$.

${ }^{\mathrm{K}} \mathrm{KNO}_{3}$ (potassium nitrate $)=38.2 \% \mathrm{~K}$.

u $70 \mathrm{~g} \cdot \mathrm{ha}^{-1}=1.0 \mathrm{oz} /$ acre

drop and with a 10 -d interval. The spray applications were made in 300 $\mathrm{L} \cdot \mathrm{ha}^{-1}$ (32.1 gal/acre) of water. The samples for fruit and leaf analysis were taken at harvest. The K concentration in the leaves was relatively low averaging only $1.56 \%$ dry weight in the untreated plot. There was a small increase in $P$ concentration of fruit and leaves in response to treatments and no effect on $\mathrm{K}$ concentration but these differences were not statistically significant. Foliar K applications on pear claim often to increase fruit size but this effect could not be confirmed in this trial (data not shown). On apple trees $\mathrm{N}-\mathrm{P}-\mathrm{K}$ treatments are more limited in use because the $\mathrm{K}$ is considered to be potentially detrimental to leaf and apple quality. Therefore special $\mathrm{P}-\mathrm{K}$ formulations with low $\mathrm{K}$ content such as Foliphos (Goëmar, Saint Malo, France), containing $12.8 \% \mathrm{P}$ and $4.2 \%$ $\mathrm{K}$, were developed for apple trees. Excess Kcan cause serious problems of leaf drop on susceptible apple cultivars such as 'Golden Delicious' or 'Cox's Orange Pippin'. This could be explained as an induced $\mathrm{Mg}$ deficiency or as an induction of the typical leaf spots causing leaf drop problems. Potassium can affect fruit quality by competing with $\mathrm{Ca}$ and in this way causing storage disorders such as bitterpit and internal breakdown. On the other hand, it is also risky to adopt of potassophobia. In many apple orchards that have not received Kapplications for several consecutive years, $\mathrm{K}$ availability has become limited and correction has become necessary. This can be achieved by immediate $\mathrm{P}-\mathrm{K}$ leaf applications to prevent deficiency symptoms on the leaves during season combined with soil applications.

Calcium. Foliar applications of $\mathrm{Ca}$ to improve fruit quality and storability is a standard practice in Belgium. Many different $\mathrm{Ca}$ formulations have been tested in our fruit nutrition trials over the last 20 years, but none of them were superior to the standard compounds $\mathrm{Ca}\left(\mathrm{NO}_{3}\right)_{2}$ and $\mathrm{CaCl}_{2}$. On 'Jonagold' standard Ca treatments as $\mathrm{Ca}\left(\mathrm{NO}_{3}\right)_{2}$ containing $15.5 \% \mathrm{~N}$ and $24.3 \% \mathrm{Ca}(\mathrm{wt} / \mathrm{wt})$, start at the end of June, with six treatments at a dose of $1.82 \mathrm{~kg} \cdot \mathrm{ha}^{-1}(1.62 \mathrm{lb} / \mathrm{acre})$ of $\mathrm{Ca}$ and are followed by $\mathrm{CaCl}_{2}$ treatments, containing $15.7 \% \mathrm{Ca}(\mathrm{wt} / \mathrm{vol})$, shortly before harvest time with four treatments at a dose of $785 \mathrm{~g} \cdot \mathrm{ha}^{-1}$ (11.2 $\mathrm{oz} / \mathrm{acre}$ ) of Ca. It is sometimes difficult to demonstrate the positive effects of these Ca treatments in a single trial as other factors such as tree $\mathrm{K}$ and $\mathrm{Mg}$ status, rootstock, tree vigor and crop load may affect fruit Ca nutrition (Fallahi et al., 1985). Storage characteristics of fruit are becoming more and more important because of the requirements for new storage facilities operated under ultra low oxygen (ULO) storage conditions. Storage capacity of fruit can be judged objectively by determining the fruit mineral composition before harvest (Marcelle et al., 1989; Bramlage et al., 1985). This allows classification of fruit into those with and without storage capacity. This early fruit analysis prevents important economic losses during storage.

Magnesium. Magnesium is one of the elements which can be applied very efficiently via foliar applications. The best timing for foliar applications is during the post bloom period with the last application recommended around June drop fruitfall. Later applications can interfere with the storage

Table 2. Effect of foliar Mg application on leaf mineral composition (July) and on Mg deficiency symptoms (August) on 'Idared' and 'Gloster' apples (1991).

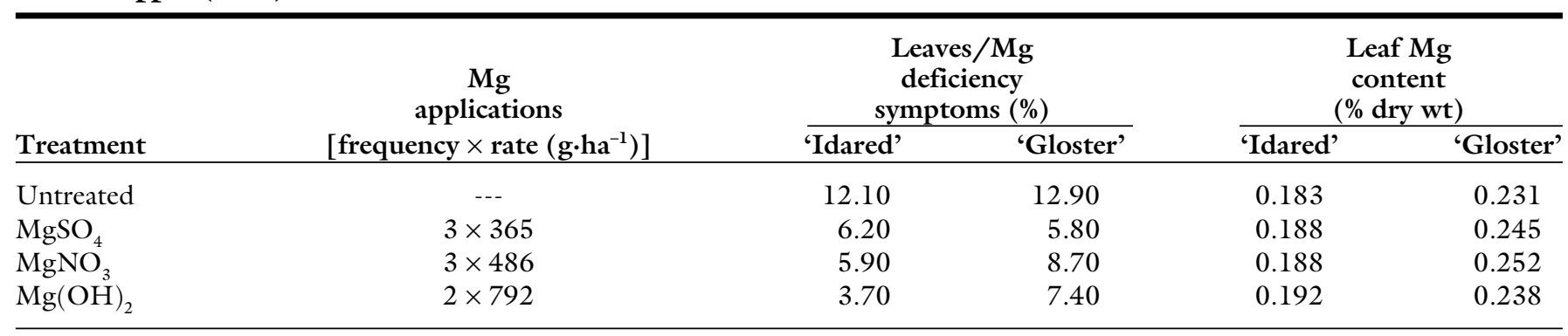

${ }^{\mathrm{z}}$ No statistical differences at $P=0.05$.

${ }^{y} \mathrm{MgSO}_{4}$ (magnesium sulphate $)=3.6 \% \mathrm{Mg}$.

${ }^{\mathrm{x}} \mathrm{MgNO}_{3}$ (magnesium nitrate) $=8.7 \% \mathrm{Mg}$.

${ }^{\mathrm{w}} \mathrm{Mg}(\mathrm{OH})_{2}($ magnesium hydroxide $)=19.8 \% \mathrm{Mg}$.

v70 $\mathrm{g} \cdot \mathrm{ha}^{-1}=1.0 \mathrm{oz} /$ acre 
Table 3. Effect of different B applications on 'Golden Delicious' apples on leaf mineral composition and on fruit skin quality.

\begin{tabular}{|c|c|c|c|c|c|c|c|}
\hline Treatment & Mineral & $\begin{array}{c}\text { Applications } \\
{\left[\text { frequency } \times \text { rate }\left(\mathrm{g} \cdot \mathrm{ha}^{-1}\right)\right]}\end{array}$ & \multicolumn{2}{|c|}{ (\% dry wt) } & \multicolumn{2}{|c|}{$\left.\mu g^{\prime} g^{-1}(p p m)\right]$} & $\begin{array}{l}\text { Fruit without } \\
\text { russeting (\%) }\end{array}$ \\
\hline Untreated & & --- & 0.249 & 44 & 160 & 29.0 & 13.0 \\
\hline +Solubor & $\mathrm{B}$ & $3 \times 372$ & & & & & \\
\hline Mancozeb & Mn & $3 \times 167$ & & & & & \\
\hline (alternated) & $\mathrm{Zn}$ & $3 \times 20$ & & & & & \\
\hline
\end{tabular}

${ }^{\mathrm{z}} \mathrm{MgSO}$ (magnesium sulphate) $=3.6 \% \mathrm{Mg}$.

ySolubor (BASF Aktiengesellschaft, Limburgerhof, Germany) $=20.8 \%$ B.

${ }^{\mathrm{x}}$ Mancozeb $80 \mathrm{WP}=16.7 \% \mathrm{Mn}$ and $2 \% \mathrm{Zn}$.

wNutribor (BASF Aktiengesellschaft, Limburgerhof, Germany) $=8 \% \mathrm{~B}, 2.1 \% \mathrm{Mg}, 1 \% \mathrm{Mn}$, and $0.1 \% \mathrm{Zn}$.

v70 $\mathrm{g} \cdot \mathrm{ha}^{-1}=1.0 \mathrm{oz} /$ acre .

${ }^{\star *}$ Significantly different at $P=0.01$

capacity of the fruit because $\mathrm{Mg}$ is a bivalent ion which can interfere with fruit $\mathrm{Ca}$. Standard treatments of $\mathrm{Mg}$ use the magnesium sulphate form $\left(\mathrm{MgSO}_{4}\right)$, containing $9.6 \% \mathrm{Mg}$, the magnesium nitrate form $\left[\mathrm{Mg}\left(\mathrm{NO}_{3}\right)_{2}\right]$ [with $9.5 \% \mathrm{~N}$ and $8.1 \% \mathrm{Mg}(\mathrm{w} / \mathrm{v})$ ] or the magnesium hydroxide form $\left[\mathrm{Mg}(\mathrm{OH})_{2}\right](19.8 \% \mathrm{Mg})$, which are applied at a dose of $0.96 \mathrm{~kg} \cdot \mathrm{ha}^{-1}(0.85$ $\mathrm{lb} /$ acre $), 486 \mathrm{~g} \cdot \mathrm{ha}^{-1}(6.9 \mathrm{oz} /$ acre $)$ and $0.79 \mathrm{~kg} \cdot \mathrm{ha}^{-1}(0.70 \mathrm{lb} /$ acre $)$ of $\mathrm{Mg}$ per treatment, respectively.

Some effects of $\mathrm{Mg}$ treatments applied post bloom on leaf mineral composition and on leaf deficiency symptoms on 'Idared' and 'Gloster' apples are given in Table 2 . The applications were made with a 2 -week interval in the post bloom period. The Mg deficiency symptoms were counted on 1-year-old shoots at the end of August about 6 weeks before harvest. Both apple cultivars are considered to be susceptible to $\mathrm{Mg}$ deficiency symptoms and showed reductions in symptoms expression after the $\mathrm{Mg}$ foliar treatments, but the differences were not statistically different. There was also no difference between the three $\mathrm{Mg}$ foliar treatments in leaf $\mathrm{Mg}$ concentration even though the amount of $\mathrm{Mg}$ applied per hectare and per treatment was different. The values in the table are the mean value of the four replicates and are compared with the control plot.

Magnesium can also be applied on the soil using a Ca formulation containing a low amount of about 3\% to $6 \% \mathrm{Mg}$. A Ca application of $2 \mathrm{t} \cdot \mathrm{ha}^{-1}$ (1784 lb/acre) corresponds with an application of 60 to $120 \mathrm{~kg} \cdot \mathrm{ha}^{-1}$ (53 to $107 \mathrm{lb} / \mathrm{acre}$ ) of $\mathrm{Mg}$. In this way, the correction of the soil $\mathrm{pH}$ can be combined with an increase of the $\mathrm{Mg}$ content of the soil. Higher amounts of $\mathrm{Mg}$ can unbalance the nutritional equilibrium in the soil and cause an increased $\mathrm{K}$ pressure in the soil solution.

BORON APPLICATION. Boron can be applied during bloom at a very low dose in order to improve pollen germination and pollen tube growth which should result in an improved fruit set (Link, 1974). With this aim, a liquid B and $\mathrm{Mg}$ preparation Goemar BM86 (Goëmar, Saint Malou, France), containing $3.6 \% \mathrm{Mg}$ and $2.5 \% \mathrm{~B}_{2} \mathrm{O}_{3}$ based on a seaweed extract was designed. To ensure that $\mathrm{B}$ is not the limiting factor for fruit set, several Goemar BM86 treatments are recommended including the first at balloon stage just before bloom, a second during full bloom, and a last application at the end of bloom. B applications during bloom are a common practice in pear growing. On apple, B applications are only made when fruit set is problematic. A second aim of B applications is to reduce russeting on the fruit skin. This is an important fruit quality factor on apple cultivars such as 'Golden Delicious', and in some years 'Jonagold'. B deficiency causes irregular growth of plant tissue which results in a typical russeting of the fruit skin or in corky tissue around the lenticels of the bark (frog skin bark).

Standard B applications are however made mostly as Solubor $(20.8 \%$ B); BASF Aktiengesellschaft, Limburgerhof, Germany) or Solubor DF [17.4\% B; BASF Aktiengesellschaft, Limburgerhof, Germany] treatments in the post bloom period and are often combined with other nutrients such as $\mathrm{Mg}$ and/or Mn. When necessary, the first treatment is made before bloom in the balloon stage and is followed by three $B$ treatments in the post bloom period with an interval of 2 weeks. Special foliar spray mixtures such as
Nutribor (BASF Aktiengesellschaft, Limburgerhof, Germany) have been developed with certain additional nutrient elements. Nutribor is a compound which contains $8 \% \mathrm{~B}, 2.1 \% \mathrm{Mg}$, $1 \% \mathrm{Mn}$, and $0.1 \% \mathrm{Zn}$.

Some results of $\mathrm{B}$ applications on leaf mineral composition and on fruit skin quality of 'Golden Delicious' are summarized in Table 3 . The values in the table are the mean value of the four replications and are compared with the untreated plot.

It is clear that B and Mn foliar applications are reflected in the leaf analysis on 1-year-old shoots in July. For $\mathrm{Mg}$ and $\mathrm{Zn}$ there was an increase but the differences were not significant. In this trial, the standard orchard treatment included fungicides containing Mn which explains the high leaf Mn concentration in the untreated plot. There was a tendency to better fruit skin quality in the Solubor-treated plot.

\section{Other microelements}

Manganese and zinc are two important microelements for leaf quality. In standard orchards, the tree requirements for both elements were met by the application of dithiocarbamate fungicides (Quast, 1986). In integrated fruit production on apple, the use of these fungicides is limited because of their toxicity to the predatory mite, Typhlodromus pyri, when they are used in repeated treatments. Therefore three treatments at a lower dose of $1 \mathrm{~kg} \cdot \mathrm{ha}^{-1}$ (0.89 lb/acre) can be applied as foliar nutrition (Table 4 ). The data are the mean value of four replicates and are compared with the untreated control plot. Special foliar spray formulations for $\mathrm{Mn}$ and $\mathrm{Zn}$ were developed for integrated fruit production systems, including Mantrac (PHOSYN plc, York, United Kingdom) containing 
$500 \mathrm{~g} \cdot \mathrm{L}^{-1}(4.17 \mathrm{lb} / \mathrm{gal})$ of Mn, Zinflow (PHOSYN plc, York, United Kingdom) containing $700 \mathrm{~g} \cdot \mathrm{L}^{-1}(5.83 \mathrm{lb} /$ gal) of $\mathrm{Zn}$, and Aseptaman (ASEPTA, Delft, the Netherlands), a lignine carboxylate formulation containing $60 \mathrm{~g} \cdot \mathrm{L}^{-}$ ${ }^{1}(0.5 \mathrm{lb} / \mathrm{gal})$ of $\mathrm{Mn}$. Manganese treatments can be made after bloom or during season and are reflected as well in the leaf as in the fruit mineral content (Table 5). The data present the mean value of the four replicates and are compared with the untreated control plot.

Manganese and zinc are routinely applied during the post bloom period with the aim of improving leaf quality. On bicolored apple cultivars like 'Jonagold', summer treatments of Mn are made with the aim of improving the green background color of the fruit (Deckers et al., 1997). The results of these summer treatments can not be guaranteed because green background color can be influenced by more than one factor. $\mathrm{N}$ and $\mathrm{K}$ level also are considered to be important for green background color.

Microelements are often applied using complex nutrient mixtures such as Basfoliar formulations (BASF Aktiengesellschaft, Limburgerhof, Germany). It is the aim with these foliar sprays to combine the application of macro-elements and microelements. In Table 6 the results of seven treatments of Basfoliar 36E (BASF Aktiengesellschaft, Limburgerhof, Germany), containing 36.5\% N, 2.46\% $\mathrm{Mg}, 1.35 \% \mathrm{Mn}, 0.037 \% \mathrm{Fe}, 0.27 \% \mathrm{Cu}$ and $0.014 \% \mathrm{Zn}(\mathrm{wt} / \mathrm{wt}$ ), at a dose of $11.8 \mathrm{~L} \cdot \mathrm{ha}^{-1}$ (1.30 gal/acre) applied during season with a 2 -week interval on apple trees are summarized. The data represent the mean value of the four replicates and are compared with the untreated control plot. Leaf analysis of the leaves of the l-year-old shoots at harvest on 'Boskoop' (1998), 'Jonagold' (1998) and 'Cox's Orange Pippin' (1987) apples and fruit analysis at harvest was undertaken. On 'Cox's Orange Pippin', the effect of Basfoliar Combistipp (BASF Aktiengesellschaft, Limburgerhof, Germany) was studied. Basfoliar Combistipp contains $21.5 \% \mathrm{CaO}, 14.4 \% \mathrm{~N}, 0.84 \% \mathrm{Mg}$, $0.58 \% \mathrm{Mn}, 0.014 \% \mathrm{Zn}$, and $0.29 \% \mathrm{~B}$ ). The leaves were washed prior to chemical analysis in a $0.2 \%$ solution of citric acid. The fruit were not washed while the proportion fruit skin versus fruit flesh is relatively low. Some effects of $\mathrm{Mg}$ in the Basfoliar 36E and of $\mathrm{Mn}$ in

Table 4. The effect of dithiocarbamate fungicide treatments after flowering on the Mn and $\mathrm{Zn}$ leaf concentration in June in 'Jonagold' apples.

\begin{tabular}{lcccc}
\hline Treatment & Mineral & $\begin{array}{c}\text { Applications } \\
{\left[\text { frequency } \times \text { rate }\left(\mathbf{g} \cdot \mathbf{h a}^{-1}\right)\right]}\end{array}$ & \multicolumn{2}{c}{$\begin{array}{c}\text { Leaf concn } \\
{\left[\mu \mathbf{g}^{-1}(\mathrm{ppm})\right]}\end{array}$} \\
\hline Untreated & & -- & 34 & $\mathbf{M n}$ \\
Aseptaman & $\mathrm{Mn}$ & $3 \times 120$ & 31 & 56 \\
Mancozeb & $\mathrm{Mn}$ & $3 \times 160$ & $51^{*}$ & $73^{*}$ \\
& $\mathrm{Zn}$ & $3 \times 20$ & & $116^{\text {** }}$ \\
\hline
\end{tabular}

${ }^{\mathrm{z}}$ Aseptaman (Asepta, Delft, Netherlands) $=6 \% \mathrm{Mn}$ (wt/vol).

${ }^{\mathrm{y}}$ Mancozeb $=16 \% \mathrm{Mn}$ and $2 \% \mathrm{Zn}$.

$\mathrm{x} 70 \mathrm{~g} \cdot \mathrm{ha}^{-1}=1.0 \mathrm{oz} /$ acre.

${ }^{*},{ }^{* *}$ Significantly different at $P=0.05$ and $P=0.01$, respectively.

Table 5. Effect of Mn treatments during the growing season on the Mn concentration ofleaves and fruit at harvest in 'Jonagold' apples.

\begin{tabular}{|c|c|c|c|c|}
\hline \multirow[b]{2}{*}{ Treatment } & \multirow[b]{2}{*}{ Mineral } & \multirow{2}{*}{$\begin{array}{c}\text { Applications } \\
{\left[\text { frequency } \times \text { rate }\left(\mathrm{g} \cdot \mathrm{ha}^{-1}\right)\right]}\end{array}$} & \multicolumn{2}{|c|}{$\begin{array}{c}\text { Mn concn } \\
{\left[\mu \mathrm{g} \cdot \mathrm{g}^{-1}(\mathrm{ppm})\right]}\end{array}$} \\
\hline & & & Leaf & Fruit \\
\hline \multicolumn{5}{|l|}{ Trial 1} \\
\hline Untreated & & --- & 55 & 3.8 \\
\hline Aseptaman & $\mathrm{Mn}$ & $6 \times 120$ & $149^{* *}$ & $5.6^{* *}$ \\
\hline \multirow[t]{2}{*}{ Mancozeb } & $\mathrm{Mn}$ & $3 \times 160$ & $145^{* *}$ & $6.4^{*}$ \\
\hline & $\mathrm{Zn}$ & $3 \times 20$ & & \\
\hline +Maneb & Mn & $6 \times 167$ & & \\
\hline Maneb & $\mathrm{Mn}$ & $6 \times 167$ & $134^{* *}$ & $5.3^{* \star}$ \\
\hline \multicolumn{5}{|l|}{ Trial 2} \\
\hline Untreated & & -- & 71 & 5.1 \\
\hline MnSO4 & Mn & $6 \times 224$ & $267^{* *}$ & $8.7^{* \star}$ \\
\hline Mantrac & $\mathrm{Mn}$ & $6 \times 125$ & $143^{* *}$ & 6.1 \\
\hline Mantrac & $\mathrm{Mn}$ & $6 \times 250$ & $245^{* *}$ & $8.8^{* \star}$ \\
\hline
\end{tabular}

${ }^{\mathrm{z}}$ Aseptaman (Asepta, Delft, Netherlands) $=6 \% \mathrm{Mn}(\mathrm{wt} / \mathrm{vol})$.

${ }^{y}$ Mancozeb $=16 \% \mathrm{Mn}$ and $2 \% \mathrm{Zn}$.

${ }^{\mathrm{x}} \mathrm{Maneb}=16.7 \% \mathrm{Mn}$.

${ }^{\mathrm{w}} \mathrm{MnSO}_{4}$ (manganese sulphate) $=32 \% \mathrm{Mn}$.

${ }^{\mathrm{v}}$ Mantrac (Phosyn plc, York, U.K.) $=50 \% \mathrm{Mn}(\mathrm{wt} / \mathrm{vol})$.

u $70 \mathrm{~g} \cdot \mathrm{ha}^{-1}=1.0 \mathrm{oz} /$ acre.

${ }^{\star *}$ Significantly different at $P=0.01$.

the Basfoliar Combistipp are reflected in the results of the leaf analysis at harvest, but not in the fruit analysis. The repeated copper treatments in the Basfoliar 36E resulted in a cumulative effect of copper on the leaves with some light phytotoxicity on the underside of the leaves in some years [symptoms similar to a rust mite (Aculus schlechtendali) attack].

The effect of B applications in the Basfoliar Combistipp was also measured in the fruit at the end of the season. Although it is not easy to demonstrate the effects of a significant increase in one microelement, it is generally accepted in orchard nutrition management that $\mathrm{Mg}$, $\mathrm{Mn}$, and $\mathrm{Zn}$ are important elements for leaf quality and $\mathrm{B}$ is important for the final fruit skin quality and for the presence of russeting.

Iron and copper are usually sufficient in conventionally managed Bel- gian orchards. For $\mathrm{Cu}$ there is no need for special treatments because of fungicide treatments in the beginning and the end of the season. In IFP systems, $\mathrm{Cu}$ is completely banned as a fungicide treatment and this could change the nutritional status of apple and pear trees after some years. Iron deficiency symptoms are often linked with high $\mathrm{pH}$ values in the soil and can be treated by leaf applications of $\mathrm{Fe}$ chelates such as ethylenediaminetetra-acetic acid (EDTA) or by soil applications of Feethylenediaminedihydrogen-acetic acid (Fe-EDDHA). Leaf Fe applications often result in irregular green spots on the leaves while soil applications of $\mathrm{Fe}$ are more uniform in result.

\section{Conclusion}

Foliar nutrition in Belgian fruit growing is a common practice for elements such as $\mathrm{N}, \mathrm{Mg}, \mathrm{B}, \mathrm{Mn}$, and $\mathrm{Zn}$. 
Table 6. Leaf and fruit analysis at harvest for 'Boskoop', 'Jonagold', and 'Cox's Orange Pippin' apples.

\begin{tabular}{|c|c|c|c|c|c|c|c|c|c|c|}
\hline \multirow[b]{2}{*}{ Cultivar } & & $\mathbf{N}$ & $\mathbf{P}$ & $\mathbf{K}$ & $\mathrm{Ca}$ & $\mathrm{Mg}$ & $\mathrm{Zn}$ & $\mathrm{Cu}$ & Mn & $\mathrm{Fe}$ \\
\hline & & \multicolumn{5}{|c|}{ (\% dry wt) } & \multicolumn{4}{|c|}{$\left[\mu \mathrm{g} \cdot \mathrm{g}^{-1}(\mathrm{ppm})\right]$} \\
\hline \multicolumn{11}{|l|}{ 'Boskoop' 1998} \\
\hline \multirow[t]{2}{*}{ Untreated } & Leaf & 2.06 & 0.250 & 1.51 & 2.000 & 0.284 & 50.0 & 7.0 & 34.0 & 99.0 \\
\hline & Fruit & 0.28 & 0.088 & 0.99 & 0.025 & 0.035 & 10.4 & 2.8 & 2.7 & 15.8 \\
\hline \multirow{2}{*}{$\begin{array}{l}\text { Basfoliar } 36 \mathrm{E} \\
\quad\left(7 \times 11.8 \mathrm{~L} \cdot \mathrm{ha}^{-1}\right)\end{array}$} & Leaf & 2.18 & $0.182^{*}$ & 1.43 & 2.070 & 0.324 & 52.0 & 7.0 & 38.0 & 104.0 \\
\hline & Fruit & 0.36 & 0.086 & 1.01 & 0.026 & 0.037 & 10.8 & 3.1 & 3.0 & 17.4 \\
\hline \multicolumn{11}{|l|}{ 'Jonagold' 1998} \\
\hline \multirow{2}{*}{ Untreated } & Leaf & 1.68 & 0.347 & 1.63 & 1.910 & 0.245 & 50.0 & 6.0 & 37.0 & 91.0 \\
\hline & Fruit & 0.20 & 0.082 & 0.91 & 0.021 & 0.029 & 28.9 & 2.4 & 2.9 & 9.9 \\
\hline \multirow{2}{*}{$\begin{array}{l}\text { Basfoliar } 36 \mathrm{E} \\
\quad\left(7 \times 11.8 \mathrm{~L} \cdot \mathrm{ha}^{-1}\right)\end{array}$} & Leaf & $1.96^{* *}$ & $0.174^{* *}$ & $1.38^{*}$ & 1.960 & 0.252 & 52.0 & 6.0 & 36.0 & 91.0 \\
\hline & Fruit & 0.23 & $0.073^{* *}$ & 0.83 & 0.020 & 0.029 & 21.7 & 2.1 & 2.9 & 11.5 \\
\hline \multicolumn{11}{|c|}{ ‘Cox’s Orange Pippin’ 1987} \\
\hline \multirow[t]{2}{*}{ Untreated } & Leaf & 2.53 & 0.172 & 1.55 & 0.860 & 0.173 & 90.0 & 11.0 & 56.0 & 112 \\
\hline & Fruit & 0.45 & 0.072 & 0.90 & 0.046 & 0.038 & --- & --- & --- & 24.7 \\
\hline \multirow{2}{*}{$\begin{array}{l}\text { Basfoliar Combistip } \\
\left(4 \times 6.0 \mathrm{~L}^{-} \cdot \mathrm{ha}^{-1}\right)\end{array}$} & Leaf & 2.35 & 0.163 & 1.55 & 0.920 & 0.177 & 88.0 & 11.0 & $98.0^{* *}$ & 111 \\
\hline & Fruit & 0.48 & 0.067 & 0.90 & 0.048 & 0.039 & --- & $\cdots$ & --- & $32.5^{*}$ \\
\hline
\end{tabular}

${ }^{\mathrm{z}}$ Basfoliar 36 ${ }^{\mathrm{E}}$ (BASF Aktiengesellschaft, Limburgerhof, Germany) = 36.5\% N, 2.46\% Mg, 1.35\% Mn, 0.037\% Fe, 0.27\% Cu, and 0.014\% Zn.

yBasfoliar Combistip (BASF Aktiengesellschaft, Limburgerhof, Germany) $=21.5 \% \mathrm{Ca}, 14.4 \% \mathrm{~N}, 0.84 \% \mathrm{Mg}, 0.58 \% \mathrm{Mn}, 0.014 \% \mathrm{Zn}$, and $0.29 \% \mathrm{~B}$.

${ }^{\mathrm{x}} 1.0 \mathrm{~L} \cdot \mathrm{ha}^{-1}=0.11 \mathrm{gal} /$ acre.

*,** Significantly different at $P=0.05$ and $P=0.01$, respectively.

For these elements the effect of foliar applications is often evident in the results of leaf analysis during the season and with these treatments it is often possible to prevent deficiency symptoms later in season and to improve some aspects of fruit quality (e.g., fruit skin russeting, green background color). For other elements like $\mathrm{K}, \mathrm{P}$, and $\mathrm{Ca}$ it is not so easy to show the positive effect of foliar application on leaf or fruit mineral composition because uptake is relative complex and is influenced by many factors and interactions.

For all leaf nutrition programs it is very difficult to determine the effect on the productivity of fruit trees over a longer period of several years.

\section{Literature cited}

Bramlage W.J., S.A. Weis, and M. Drake. 1985. Predicting the occurrence of post storage disorders of ' $\mathrm{Mc}$ Intosh' apples from preharvest mineral analysis. J. Amer. Soc. Hort. Sci. 110:493-498.

Deckers, T., E. Daemen, K. Lemmens, and C. Missotten. 1997. Influence of foliar applications of Mn during summer on the fruit quality of Jonagold. Acta Hort. 448:467-473.

Fallahi E., D.G. Richardson, M.N. Westwood, and M.H. Chaplin. 1985. Relationship among mineral nutrition, ethylene and postharvest physiology in apples on six rootstocks. Scientia Hort. 25:163175.

Link H. 1974. Lucas Anleitung zum Obstbau. Chpt. Ernährung und Dngung. Verlag Eugen Ulmer, Stuttgart, p. 233263.

Marcelle R.D., W. Porreye, T. Deckers, P. Simon, G. Goffing, and M. Herregods. 1989. Relationship between fruit mineral composition and storage life of apples cv. 'Jonagold'. Acta Hort. 258:373-378.

Quast P., 1986. Düngung, Bewässerung und Bodempflege im Obstbau. Chapter: Nährstoffversorgung, p. 90-164. Verlag Eugen Ulmer, Stuttgart. 